Seminário de Pesquisa

Programa de Pós-Graduação

Design FAU USP

\title{
Imagens digitais pela divulgação científica: 0 caso do Covid-19 nas mídias sociais
}

\author{
Susana Narimatsu Sato, Clice de Toledo Sanjar Mazzilli
}

\section{design da informação; comunicação científica; imagens digitais}

A nova visibilidade da ciência em decorrência da crise do Covid-19 tem evidenciado um problema antigo: apesar da consciência dos cientistas sobre sua responsabilidade de difundir o conhecimento e avanços alcançados no âmbito de suas pesquisas, a comunicação entre instituições científicas e sociedade costuma ser intrincada. Jargões técnicos, linguagem hermética e modelos inacessíveis agravam o distanciamento entre a academia e um público mais amplo. Esta pesquisa investiga o emprego de recursos imagéticos na democratização e divulgação de conhecimentos científicos dentre

Curso

Doutorado

\section{Linha de Pesquisa \\ Design: Processos e Linguagens}

\section{Susana Narimatsu Sato}

Graduada em Arquitetura e Urbanismo pela FAU-USP, mestre em Ciências da Comunicação pela ECA-USP e doutoranda do Programa de Pós-graduação em Design (FAU-USP).

e-mail: snsato@usp.br Lattes: http://lattes.cnpq. br/4142168150606251 Orcid: https://orcid.org/00000003-4602-1133

\section{Clice de Toledo Sanjar Mazzilli} Graduada em Arquitetura e Urbanismo pela FAU-USP, onde realizou mestrado, doutorado e livre-docência na área de Programação Visual. Leciona no Departamento de Projeto da FAU-USP desde 2001 e atualmente coordena o Programa de Pós-graduação em Design e o Laboratório de Programação Gráfica (LPG).

e-mail: clice@usp.br

Lattes: http://lattes.cnpq. $\mathrm{br} / 9635315172253349$

Orcid: https://orcid.org/00000002-6903-9099 a comunidade leiga. Por seu "caráter direto" (DONDIS, 2007: 6) e engajador, as imagens favorecem a transmissão de mensagens complexas, o que torna benéfica, por exemplo, a associação entre cientistas e designers para representarem os "dados na linguagem das pessoas, e não na linguagem dos dados" (CIUCCARELLI, 2012: 82). Considerando a fácil reprodução e disseminação das imagens digitais (MONTAÑEZ, 2016), concentramo-nos em visualizações que circulam em mídias sociais. Pela recuperação e sistematização de rastros deixados na internet, das "zonas de contato" (FAUSTO NETO, 2010: 65), espera-se identificar aspectos formais (sintáticos) que impulsionam a circulação e a propagação das imagens. Perscrutaremos elementos visuais como: técnica de produção, estrutura, diagramação, escala cromática, tipografia e propriedades multimídia. 0 corpus decorrerá de postagens que abordem a temática do Covid-19. A observação do trabalho de curadoria realizado por determinados usuários (propagadores), assim como a detecção de padrões de compartilhamento, podem favorecer o delineamento de táticas que beneficiem a difusão de conhecimento científico. 


\title{
Digital images for science communication: the case of Covid-19 on social media
}

\author{
Susana Narimatsu Sato, Clice de Toledo Sanjar Mazzilli
}

information design; scientific communication; digital images

The new visibility of Science as a result of the Covid-19 crisis has highlighted an old problem: despite the scientists' awareness of their responsibility to disseminate the knowledge and advances achieved in the scope of their research, communication between scientific institutions and society is often intricate. Technical jargons, obscure language and inaccessible models aggravate the gap between academia and a wider audience. This research investigates the use of imagetic resources in the democratization and dissemination of scientific knowledge among the lay community. Due to their engaging and "direct character" (DONDIS, 2007: 6), images favor the transmission of complex messages, which makes it beneficial, for example, the association between scientists and designers to represent "data in people's language, and not in the language of data" (CIUCCARELLI, 2012: 82). Due to digital imagery's easy reproduction and dissemination (MONTAÑEZ, 2016), we focus on visualizations that circulate on social media. By recovering and systematizing tracks left on the internet, on "contact zones" (FAUSTO NETO, 2010: 65), we expect to identify formal (syntactic) aspects that drive the circulation and spread of these images. We will examine visual elements such as: production technique, structure, diagramming, chromatic scale, typography and multimedia properties. The corpus will result from posts relating to Covid-19. Observation of the curatorial work carried out by certain users (propagators), as well as the detection of sharing patterns, can favor the detection of tactics that benefit the dissemination of scientific knowledge.

\section{Referências | References}

CIUCCARELLI, P. 2012. Turning visualisations into stories and 'big pictures'. In: RENDGEN, S. \& WIEDEMANN, J. (eds.). Information Graphics: 77-95. Berlin: Taschen.

DONDIS, D. 2007. A sintaxe da linguagem visual. São Paulo: Martins Fontes. FAUSTO NETO, A. 2010. As bordas da circulação. Alceu 10(20): 55-69.

MONTAÑEZ, A. 2016. How science visualization can help save the world. In: SA Visual - Scientific American Blogs <https://blogs.scientificamerican.com/savisual/how-science-visualization-can-help-save-the-world/>, 01/12/2020.

\section{Clice de Toledo Sanjar Mazzilli}

Graduated in Architecture and Urbanism from FAU-USP, where she also completed a master's, doctoral and habilitation degree in Visual Programming. Teaches at the Design Department at FAU-USP since 2001 and coordinates the Postgraduate Program in Design and the Graphic Programming Laboratory (LPG).

e-mail: clice@usp.br

Lattes: http://lattes.cnpq. $\mathrm{br} / 9635315172253349$

Orcid: https://orcid.org/00000002-6903-9099 